\title{
THE ESTABLISHMENT OF THE PROFESSIONAL CHRISTIAN MUSIC IN THE EARLY MEDIEVAL TIME
}

\author{
Alina Riabokin \\ Department of General Pedagogics and Andragogy \\ Poltava V. G. Korolenko National Pedagogical University \\ 2 Ostrohradskyi str., Poltava, Ukraine, 36003 \\ Alinarn93@ukr.net
}

\begin{abstract}
The article deals with the formation of sacred music by Christians in the early Middle Ages. Basing on the historical sources and scientific literature, the authors show a connection between the musical traditions of Rome, the Western Goths of Spain and the empire of Charlemagne. The teaching of professional church singers, the birth of Mass, the complexity of the musical pattern of Christian singing, the educational ideas of Isidore of Seville and Alcuin of York, the metriz school timely opened by Christian mentors - all of it contributed to the formation of the early medieval educational process. Alcuin is the author of many (about 380 ) Latin instructive, panegyric, hagiographic, and liturgical poems (among the most famous are The Cuckoo (lat. De cuculo) and The Primate and Saints of the York Church (lat. De pontificibus et sanctis Ecclesiae Eboracensis)). Alcuin also wrote puzzles in poetry and prose. Alkuin conducted the extensive correspondence (with Charles the Great, Anguilbert, Pope Leo III and many others, a total of 232 letters to various people); Alcuin's letters are an important source on the history of the Carolingian society. At the Palace Academy, Alquin taught trivium and quadrivia elements; in his work On True Philosophy, he restored the scheme of the seven liberal arts, following Kassiodor's parallel between the seven arts and the seven pillars of the temple of Wisdom of Solomon. He compiled textbooks on various subjects (some in a dialogical form). The Art of Grammar (lat. Ars grammatica) and the Slovene of the Most Noble Young Man Pipin with Albin Scholastic (Lat. Disputatio regalis et nobilissimi juvenis Pippini cum Albino scholastico) became very famous. Alcuin's textbooks on dialectics, dogmatics, rhetoric, and liturgy are also known.
\end{abstract}

Keywords: Christian music, early medieval society, metriz school, mass, clergy, choir, harmonica, organics, rhythm.

DOI: 10.21303/2504-5571.2020.001319

\section{Introduction}

The formation of the professional music art began at the dawn of the Christian era, when the congregation of believers began building the first churches and temples to serve the Lord together. When reading the sacred texts, the priests sang in one sound, and the same monotonous response of the parishioners (choirs) had ceased to satisfy the aesthetic preferences of the Roman educated elite, who had adopted Christianity.

One of the first to take a deep look at this issue in the IV century c. e. was the Bishop Ambrose of Mediolan (Amvrosian chants). But here we talk about the teachers of the Western Church who raised the contribution of their predecessor to the level of vocational education - Isidore of Seville (Bishop of Seville, 570-637) and founder of the Academy of Charlemagne - Alcuin of York (735-804).

Since the mid-XIX century, many distinguished works have been devoted to these eminent Christian mentors and musicians. These are, first of all, Russian researchers G. Romanovsky, S. Panteleimonov [1, 2], foreign ones by J. Bowen, J. Churruca, G. Cohen and others [3-5]. These works testify to the importance of the legacy of Isidore of Seville and Alcuin of York in shaping the sacred music of Christianity, especially church mass. Despite the sources and the scientific literature, there is no place, where the evolution was consistently analyzed, including personal connections that appear in the relevant chain: Gregory the Great - Isidore of Seville - Alcuin of York. Therefore, the authors of this article aim to summarize the experience of becoming of the Christian music in the VI-IX century and to show it as a continuous process [6].

The aim of the study is reproduction of the establishment of the professional Christian music in the early medieval age.

\section{Materials and Method}

The spiritual revival of Visigothic Kingdom (early medieval Spain) can be traced to the years of Isidore's life from Seville. A very favorable situation for the development of Christian edu- 
cation was formed in the last three decades of the VI-th century on the peaceful Iberian Peninsula. The High Episcopal School was opened in Hispalis (Seville), making it the first university-type in Europe. Inspired by his brother Leandro, distinguished by "scholarship", Isidore of Seville, who gained encyclopedic knowledge and became the author of the educational pedagogical literature, was recognized as the sixth Doctor of the Church.

Isidore was a direct follower of the educational, scientific and educational ideas of Boethius and Cassiodorus. Protevin found far more opportunities to actually implement his own model of Christian education (doctrine). The system of ideas in the encyclopedia of Isidore from Seville on the structure of the "living" world served as the basis for writing philosophical treatises of the XVIII century.

In Latin, he was called Sanctus Isidorus Hispalensis episcopus; In modern languages Isidore of Seville, Isidore of Seville (Hispallis). Isidore interpreted the concepts and terminology for all "things", known in the XVI century, and for the first time created a research conceptual apparatus for scientific concepts that combined ancient knowledge with the foundations of Christian religion.

It is Isidore's sole responsibility to provide an early medieval science with an encyclopedia in the form of art systematization of all the knowledge he has accumulated so far and an interpretation that his contemporaries could understand. Thanks to the fully survived work of a bishop, we have the opportunity to learn how the educated elite of Spain (Visigothic Kingdom) understood pedagogy, history, geography, cosmology, theology and grammar. The scientist gave to all the congregations the form of a stable system that combined Christian faith and late antiquity.

Isidore began his encyclopedia, explaining the difference between science and art. "I don't know anything unless I study. Science is called what it teaches to everyone (discutur plena). Art (ARS) has this name because it consists of the rules of science and art (art). Others claim that the

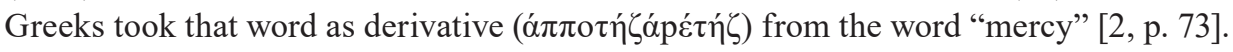

Unlike Boethius and Cassiodorus, Isidore did not divide the seven free arts into two parts, affirming the completeness and unity of basic science. According to Roman tradition, the scientist began the presentation of science in grammar and dialectics, which he considered as a practical way to study a more complex doctrine - rhetoric.

Indeed, unlike Pope Gregory I, the bishop of Seville paid less attention to the development of an integral part of the quadrium - music.

However, Isidore reproduces the complex ramifications of the musical field and explains its nature and purpose. "Music is an orientation to the rhythm and its understanding, composed of sounds and songs. This name comes from muses. Therefore, without music there is no perfect science. Without music, nothing can happen: music controls passion, shapes a different state of emotions, and how we are so excited that we are talking about the movement of blood in the middle of the veins, which is related to the power of harmony due to the rhythm of the music. The music consists of three parts: harmonics, rhythm and metrics [7].

It is known that every sound that is a component of a song has a triple nature (three sections). The first is the harmonica, which consists of the sounds of the song. The second is organic. This means the ability to master the tools. The third section of the rhythm contains a rhythm6 without which you will not be able to sing properly [1, p. 91-92].

Thus, you will meet the classification of musical art by means of expression, the methodology of the study in sections. Modern Christian music theory owes much to Isidore. At one time, his episcopal school was really preparing professional singers.

In the next VIII century, Western European countries experienced a number of serious upheavals. The powerful empire of Charlemagne was born in the heart of the European continent, when the combined forces were able to destroy the Avars, which hampered the development of culture and education by their attacks on European nations. As the status of the spiritual metropolis of Rome strengthened, the part of the Iberian Peninsula receded to the Arab world. The central figure for Christian education in the VIII century was Flakk Albin, York, the founder of a universal model that combined all the previous spiritual traditions of the early Middle Ages. He introduced the scholars of the traditions of Irish Christianity in the Frankish lands. 
We classify Alcuin's model of education as the word-wide recognized universal system of the early Middle Ages with enhanced spiritual and moral elements. It set an example for the next stage of the evolution of education in all fields of knowledge.

A real cultural uplift began in the Frankish empire during the reign of Charlemagne (768-814). This was facilitated by the active work of the king in this direction. The period is called the Carolingian Revival (768-840). Indeed, after Alcuin's moving to the Aachen Palace, a truly turbulent life began there. At that time, the Aachen Academy was already functioning, most of its members belonged to the best Frankish nobility and royal family [2, p. 101].

At that time, Alcuin wrote in his grammar book: "There is no nobler work than working on a holy book, and the clerk receives his reward. Writing a book is better than taking care of a vine. A book is for one's soul, and the vine works for one's stomach, enlightened person absorbs the wisdom of old and new teachers, for he reads the works of the revered Fathers" [2, p. 102].

Alcuin showed how and when to distribute parts of the Holy Week Mass, as reflected in music books (De Musica, De Mysterium). The scientist noted that it is necessary to pay attention to soloists, performers of "Passions", work with their facial expressions and church texts, emotions from performance, art and spirituality. Church parishioners, who listen to "Passions", should sing along with the church choir to feel the "passion" of the Lord.

Music as a subject of school education caught the attention of Charlemagne. Already in the year 787, they invited 12 singers from Rome, led by the masters Theodore and Benedict. Charlemagne sent one of them to the Mets and the other to Soissons, where he opened a song school (in meters). Bishops and monasteries were to teach church liturgy in these schools. Of course, vocal music was at the forefront in all schools, but instrumental music began to develop alongside it. At that time, a theory of music was also commissioned, which was studied in accordance with Severinus Boethius's manual [8].

This can be found in the diary of Walafrid Strabo: "Since Easter, I started playing music this year. I don't have much ability to do this art, but I am deeply convinced that I have to do it, so I studied with great interest the book of Boethius, Reading about the Concerns of the Lord, as the Most Famous Musician, wrote various hymns and songs". Tatton gave a detailed lecture on the order and interdependence of music and the rules of composition. Then he explained to us the organic characteristics of different instruments, the rules of the song, the different musical symbols, their origin and their true meaning to us. Today, learning to play musical instruments, one of us played an organ that served as the only way to accompany a temple song, another on a harp, two on a flute, one played trumpet or trombone. Someone tried to play Chizaao.

We know that in the Alcuin era, on certain holidays, liturgical dramas took place in the middle of the church, allowing students to use a variety of instruments. Indeed, scholars of this period never used the term "liturgical drama", because this action has not yet actually taken place. Cities such as Aachen and Tours were the center of Christian culture. There has been a large population of Christianity, who has long since attended the service. However, Alcuin's book on the Catholic liturgy was rewritten many times and contained detailed descriptions of sacraments and masses, so the next generation of pastors gladly introduced Alcuin York's experience in staging church dramas [5, p. 430].

Of course, the medieval folk and Christian-Catholic tradition was that Pope Gregory the Great was considered the sole creator of all choirs, and today we call the general cycle "Gregorian chant." However, this is not entirely correct. Of course, the pope created many western songs, but later versions of Antiphonary (especially the English version of the early X century) included later works. There is an assumption by art historians that some of these choirs belong to Alcuin of York [9].

Unlike Isidore from Seville, who has only featured in music in his third book, Etymology, entitled Four Mathematical Disciplines, Alcuin dedicates a thorough work to this art. Isidore considered music to be the final, combining arithmetic, geometry and astronomy, necessary for the functioning of education and church singing. In his work, De Musica Alcuin demonstrates the convenience of a special system of signs for church musicians. In his opinion, this should raise the professional level and bring the choir closer to God [10]. 
A great teacher wrote in one of his Latin letters: "Virtually every child can learn grammar, dialectics and rhetoric. Everything is different in mathematics. Not everyone understands arithmetic and geometry. In music, it's even harder. A good voice and hearing for God are given to man, and only voices can uplift the glory of the Creator. We must preserve and nurture these voices. Do not overburden them so that they may understand the treasure, God has given them, and then they will even be weary of the service of the church. [1, p. 9-11]. By the end of the XIX century, such opinion was followed by the national teachers of church music [2, p. 112].

In the context of professional music, Alcuin is considered one of the founders of the medieval European spiritual music tradition and a music theorist. His work describes in detail the system of eight full-tone frets. They will be called the church system later. Here we will meet with one of the first variations of inappropriate console and non-mathematic characters;

A significant part in Alcuin's work was the preparation and verification of singers, destined to perform mass. In the monastery of St. Martin was appointed by the best leaders of the church choir. All the rules, developed in Antiphonary by Pope Gregory the Great, were embodied here; music was studied in Latin, which was accessible and understood by the Carolingian era, sometimes sung in the native language [4, p. 81].

\section{Result}

Alcuin was a prominent poet and musician of his time. The population, two centuries after Pope Gregory increased significantly, ethnic colors appeared in standard Gregorian tunes. In the empire of Charlemagne, the parishioners of different ethnic groups went to one church. It was a church with multilingual people. Therefore, Alcuin restored the Antiphonary and supplemented it with his own work, adapted to the Latin and Frankish populations.

The Gregorian choir remained unanimous in the Alcuin era. However, the bishop was convinced that the skill of the singers and choirmasters of monasteries and churches required careful preparation. He suggested that a separate school was needed, where children could be selected according to their musical abilities - hearing, memory, rhythm.

During the life of Alcuin, this idea failed to be realized, but a special emphasis was put on preparing the choir of the Tours Monastery. After studying the trivium, the boys with nice voices and good hearing studied music deeply, and they were given much less time and attention to their skills in other "math" disciplines. Alcuin believed that the basis of the cultural tradition of the Christian temple rests on the singers. In De Musica, he used fragments of singing, useful for expanding the vocal apparatus, developing breathing, and range, drawing on the experience of the church choir of the York School, at, [2, p. 52].

Alcuin's understanding of the "teaching" and "upbringing" was almost identical. Even the term "erditio" meant both concepts at the same time. In his view, education for society was of particular importance. Most importantly, he offered a true love of mentors to the students. According to Alcuin, they should be loved and raised as their own children. He proposed three methods:

1) persuasion;

2) examples of personal behavior;

3) punishment as a means of education.

"I'm not giving any good advice, but just showing, how it should be. If that doesn't work, then I punish [4, p. 251] In other words, the teacher considered punishment the usual method of education.

However, Alcuin's approach to secular education was somewhat different. If the children were brought to the monastery almost at an unconscious (infant) age, education at the palace school required parental care. Both children and parents have the same responsibility here. The former had to study qualitatively, and the latter to control them. And ideally, according to Alcuin, both sides should have enjoyed it. This mentor-child approach to parent-child relationships has sparked much debate in the XIX century learning environment, when interest on his research resumed. [2, p. 5-6]. 


\section{Conclusions}

Thus, based on historical sources and scientific literature, we have the right to state that a new type of specialized educational institution was launched in this era - the metric school, which trained future professional church musicians. This school incorporated the consistent "scientific" tradition of Isidore of Seville and the practical work of Alcuin of York. There is every reason to believe that it emerged during the early Middle Ages, becoming a major supplier of regents, choirs and organists. The education of the children of this school was primarily based on a thorough understanding of musical subjects - church singing and instruments. However, it must be remembered that both Isidore and Alcuin were in some ways disciples of Pope Gregory the Great.

\section{References}

[1] Panteleimons, S. (1830). RGALI, t. 1345. Collection of manuscripts of writers, scientists, public figures 1669-1949 op. 1. to 1-1124. op. 1. to 1-1124. unit xp. 412. Lectures on history, 96.

[2] Romanovsky, G. I. (1361). RGALI, t. 1345. Collection of manuscripts of writers, scientists, public figures 1669-1949 op. 1. to 1-1124. op. 1. to 1-1124. unit xp. 464. Philosophical reasoning about kindness, nature, unity, etc.

[3] Bowen, J. A. (1981). History of Western education. London: Metthuen, 631.

[4] Cohen, G. (1993). Englisch religions drama. London: Macmillan, 257.

[5] Churruca, J. De. (1973). Presupuestos para el estudio delas fuentes jurídicas de San Isidoro de Sevilla. AHDE 43, 429-443.

[6] Chadwick, H. (1966) Early Christian thught and the classical tradition. Oxford University Press, 174.

[7] Bromell, D.; Aldrich, R., Wotherspoon, G. (Eds.) (2002). Alcuin. Who's who in Gay and Lesbian History: From Antiquity to World War II. Psychology Press.

[8] Boswell, J. (2015). Christianity, Social Tolerance, and Homosexuality: Gay People in Western Europe from the Beginning of the Christian Era to the Fourteenth Century. University of Chicago Press, 456.

[9] Atkinson, L. (2005). When the Pope was a Mathematician. The College Mathematics Journal, 36 (5), 354-362. doi: http:// doi.org/10.1080/07468342.2005.11922149

[10] Bullough, D. A. (2004). Alcuin: Achievement and Reputation. Being Part of the Ford Lectures Delivered in Oxford in Hilary Term 1980. Brill, 566. 